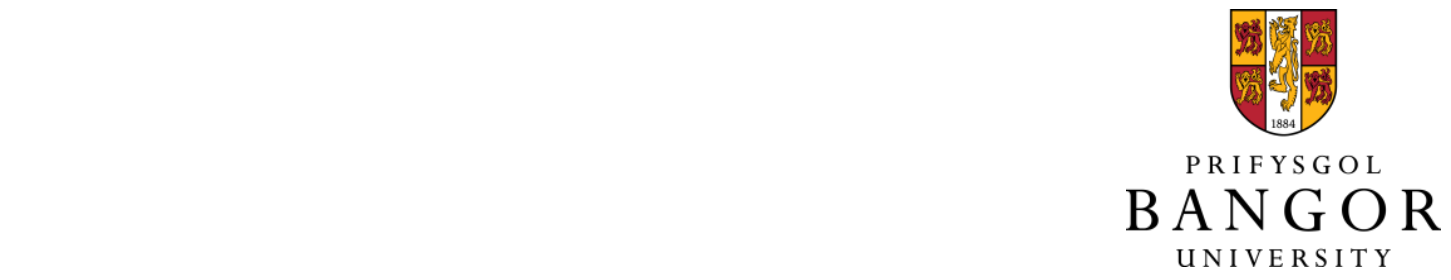

Pathways to Policy and Management: Knowledge, Process and Venue Dandy, Norman

\title{
Environmental Values
}

DOI:

10.3197/096327118X15321668325902

Published: 01/10/2018

Peer reviewed version

Cyswllt i'r cyhoeddiad / Link to publication

Dyfyniad o'r fersiwn a gyhoeddwyd / Citation for published version (APA):

Dandy, N. (2018). Pathways to Policy and Management: Knowledge, Process and Venue.

Environmental Values, 27(5), 459-465. https://doi.org/10.3197/096327118X15321668325902

\footnotetext{
Hawliau Cyffredinol / General rights

Copyright and moral rights for the publications made accessible in the public portal are retained by the authors and/or other copyright owners and it is a condition of accessing publications that users recognise and abide by the legal requirements associated with these rights.

- Users may download and print one copy of any publication from the public portal for the purpose of private study or research.

- You may not further distribute the material or use it for any profit-making activity or commercial gain

- You may freely distribute the URL identifying the publication in the public portal ?
}

Take down policy

If you believe that this document breaches copyright please contact us providing details, and we will remove access to the work immediately and investigate your claim. 


\section{Pathways to Policy and Management: Knowledge, Process and Venue}

Environmental knowledge and values permeate policy and management processes in numerous ways, with some forms often having a stronger impact than others. These processes can be relatively slow and long-term. Some, however, are more immediate and rapidly evolving. Many of us engaged in contemporary research on environmental matters in the UK are concerned with the potential shape of environmental management and governance following the UK's 'planned' departure from the European Union (EU) next year ('Brexit'). Conversations, calls for research, and workshops on the subject are happening everywhere - continually announced in email inboxes and on social media. The environment (protections, land use, resilience, change) is at the heart of the 'Brexit' debate as the UK's 'green' policies, practices and economies have evolved in a deeply mutualistic fashion with the rest of the EU's. The Natura 2000 network and 2020 climate and energy targets can be cited as examples of such co-ordinated, mutually reinforcing approaches.

Many of the questions currently being posed are long-standing and have a broadly familiar tone - How can land-managers be supported to deliver public benefits? What shape should our energy sector be in order to deliver on climate change commitments? - but have the new suffix '... following the departure of the UK from the EU?' (and with notably shorter timeframes in which to produce an answer!). However, the current deliberations do provide an opportunity to re-examine and challenge some of the core structures of EU schemes such as the much-debated Common Agricultural Policy (CAP). Certainly those in favour of leaving the EU wish to characterise it as such. Recently the UK's Prime Minister stated that leaving the CAP was a 'real opportunity for the future" ${ }^{1}$ and earlier this year another senior UK politician described the CAP as 'fundamentally flawed', 'unjust', and as producing 'perverse outcomes'. ${ }^{2}$ Claims such as these deserve attention - whatever one's thoughts about those who make them. Some see an opportunity for the UK to escape the perceived EU 'straightjacket' and create stronger, more effective environmental protections. Rigorous border controls, for example, have commonly been called for by those concerned with biosecurity. Reference has also been made to strengthening animal welfare standards in farming, and the potential for a more open approach to plant science's use of genomics.

1. Theresa May MP, speech to the Royal Welsh Show, 26 July 2018. See http://www.itv.com/ news/wales/2018-07-26/theresa-may-visits-royal-welsh-show-to-set-out-post-brexit-farming-plans/

2. Michael Gove MP, 'Farming for the next generation' speech to the Oxford Farming Conference, 4 January 2018. Text available at https://www.gov.uk/government/speeches/ farming-for-the-next-generation

Environmental Values 27 (2018): 459-465.

(C) 2018 The White Horse Press. doi: 10.3197/096327118X15321668325902 


\section{EDITORIAL}

The UK's exit from the EU presents a typical challenge for science where it engages with policy: the effective gathering and integration of knowledge into fraught processes within a defined and imminent timescale. It involves rapid identification of information and decisions about what knowledge is 'in', its mobilisation on to the right pathways, in the right format, and its effective absorption in such a way as to impact meaningfully on policy outcomes. Some universities and research institutes have been swift to adapt, seeking to organise their existing expertise to respond in appropriate ways. However, the timescales intrinsic to scenarios such as 'Brexit' present a significant challenge to some well-established academic practices. Peer-review, publication and research procurement, for example, generally operate within longer timeframes. Consequently, we are seeing some of these processes short-cut, albeit in relatively commonly experienced ways. At the receiving (policy-making) end, the Institute for Government $(\mathrm{IoG})^{3}$ noted this year that 11,500 jobs had been created in the civil service in an effort to increase capacity. For the Department for Environment, Food and Rural Affairs the IoG noted that recruitment is likely to 'fully reverse' the job cuts made subsequent to 'austerity' focused spending reviews. These saw the departure of many experienced government scientists whose knowledge is now absent from the 'Brexit' process.

How knowledge, values and expertise enter policy and management processes has been a consistent concern within the pages of Environmental Values (see Barr 2017) and the varied contributions to this issue continue this. Between them they illustrate not only the forms in which knowledge and values can be input to these processes (indigenous, experimental social survey, visualisations, ecological science), but also the diverse array of venues in which this information is used (courts, media, planning, reconciliation processes).

Shana Hirsh and Jerrold Long focus on the courts as a venue in the negotiation of adaptive management and species protection, and particularly on the role of scientific knowledge therein. Their central problem is the tension between the US Endangered Species Act's demand for the use of the 'best available science' and the flexibility and uncertainty intrinsic to adaptive management. They describe the controversies surrounding the US National Oceanic and Atmospheric Administration's (NOAA) production of 'biological opinions' (BiOps) in relation to the effect of dam operations on endangered salmon species in the Columbia River basin. These BiOps facilitated the continued operation of the federally-managed dams through findings of "no jeopardy' towards the protected species based on suggested implementation of management actions ('reasonable and prudent alternatives' - RPAs). They were, however, challenged in the courts by indigenous groups, state and NGO actors on multiple grounds, with judgements against them in relation to their use of science (particularly their catchment modelling) and the likelihood of

3. https://www.instituteforgovernment.org.uk/blog/ brexit-continuing-ramp-civil-service-workforce

Environmental Values 27.5 
certain management actions (e.g. habitat restoration) actually occurring. In 2008 the NOAA produced an Adaptive Management Implementation Plan with the goal of more effectively delivering the RPAs, however the level of uncertainty has remained, as Hirsh and Long state, 'too much for the court, even when part of a formal adaptive management plan'.

The authors seek to explain these controversies in reference to the role of non-epistemic values in science, engaging particularly with the concepts of inductive risk (which, arguably, is what adaptive management is directed towards) and pragmatic encroachment. Recognising that any given scientific conclusion may be wrong (inductive risk), non-epistemic values such as ethical standards and tolerances play a necessary role in accepting or rejecting science. Crucially, this can lead to a requirement for higher levels of certainty in cases where being wrong matters more - for example, when irreversible species extinction is a possibility. Alongside this, pragmatic encroachment recognises that absolute scientific certainty is not possible and therefore that any management actions can only be based on 'sufficient reason'. As the authors note, 'what is considered reasonable ... is contingent upon values and culture'. In describing the role that non-epistemic values play, and locating the core actors (notably the courts and the NOAA) as rooted in different traditions of science and as holding differing values and societal goals, the paper clarifies the reasons for the emergence of the various conflicts in this case. It is argued that environmental management processes can be strengthened by articulating standards at all stages within associated scientific and decision-making processes, along with the non-epistemic values that frame them.

Lidia Greco and Francesco Bagnardi's paper offers an analysis of responses to the environmental pollution and associated ill health caused by Europe's largest steel plant at Taranto in southern Italy. Established over fifty years ago, this huge industrial complex, its management and environmental impact had consistently been the focus of critical attention from the media, environmental organisations and workers. The authors identify its privatisation in the mid1990 s as the key point in the evolution of action to address its environmental impacts. The move away from public control resulted in the 'collapse' of the albeit weak pre-existing regulatory framework and erosion of the broad socioeconomic compromises that underpinned the plant's generally unopposed operation (based on providing economic development and jobs). As in the case of salmon protection above, the courts have been a consistent venue for contest in this case and local magistrates were critical to triggering governmental intervention in 2012.

The authors describe how both the opposing 'industrialist' and 'environmentalist' movements in this case mobilise primarily technical and scientific knowledge to support their positions: the 'industrialist' position being strongly reliant on ecological modernisation to maintain the 'sustainable' operation of the plant, while the 'environmentalist' position draws primarily on health 


\section{EDITORIAL}

data to advocate for the closure of the plant. The paper's central contention is, however, that neither position challenges existing power relations and roles: the debate is 'polarised but not politicised'. Actors attempting to make this challenge have found it virtually impossible to gain purchase within the debate. Both established positions, it is argued, ignore the case's core question of environmental justice - the fact that local workers will most likely continue to feel social, economic and environmental impacts associated with the plant regardless of its future.

The ways in which indigenous knowledge can enter, and improve, environmental management and policy processes has been a consistent theme of Environmental Values (e.g. Bach and Larson, 2017; Bhattacharyya and Larson 2014). This is continued within the pages of this issue by Esme Murdock who makes plain that established judicial venues and processes are not adequate for addressing all matters of environmental degradation. She addresses the need for reconciliation in cases of settler land seizure from indigenous communities, arguing convincingly that its ecological effects are an 'instantiation of violent relations' that demand such reconciliation. However, it is argued that familiar approaches, such as the 'Truth and Reconciliation Commission' (TRC) model, systematically omit environmental dimensions of harm (ecological violence). These are often of primary importance to displaced indigenous communities whose history of relations with the land are erased by land seizure. Such models of reconciliation extend and perpetuate the dominance of euro-descendent cosmologies and epistemologies by failing to comprehend indigenous positionalities - especially in relation to land - but also by measuring 'truth by settlers' institutional legal-juridical standards'. Difficulties particularly arise from the differences between settler and indigenous conceptualisations of land: as something to be owned or something to belong to and hold reciprocal relations with.

In its central use of testimony (for generating proof of injustice), the TRC model can furthermore deafen its participants to indigenous epistemologies. The audience must be 'capable of hearing' and accepting indigenous testimony - whilst situated in a context where the standards proof are set by institutions that are an artefact of settler domination. This operates in conjunction with the potential for 're-victimisation' of those testifying - a problem now recognised within a number of judicial processes. Individuals may feel shame at having to 'prove their oppression to their oppressors'. Having levelled these criticisms, Murdock hints at some light at the end of the tunnel, identifying the co-management of Nmé (lake sturgeon) in the Big Manistee watershed in the Great Lakes region as an exemplar of what she terms successful 'deep reconciliation'.

This issue's remaining papers focus on climate change and, in particular, consider the ways in which information and knowledge operates within 'public' discourses. Time and again it is apparent that decisions by public 
officials and others are moderated by their perceptions of public preferences for management options and their assumptions about processes and appropriate messages for engagement.

Samuel Merrill and co-authors focus on options for financing protection for coastal communities vulnerable to climate-enhanced flood hazards. The values underpinning flood governance and management in the United States have evolved via a lengthy process wherein expert knowledge has continually interacted with policy and public discourses (Bergsma, 2016). Within this, a long standing aspect of the climate change adaptation debate at this scale has been whether the costs of protection should be met directly by local beneficiaries or collectively through general taxation. In this paper the authors analyse this question through participatory case-study research in Florida. They show that those methods that place the cost burden directly on beneficiaries (e.g. lowinterest loans for property owners) are considered most acceptable. Options to raise money more collectively (through taxation or utility bills) are less acceptable. Whilst the overall level of acceptability varied somewhat, this rank ordering of preferences remained relatively consistent across respondent categories of reported environmental values (assessed in reference to the 'new ecological paradigm' scale) and party political affiliation. Low interest loans in particular remained the most preferred option.

An especially interesting element of this study is the use of visualisation within the participatory research process to bring knowledge of the potential impacts of flooding into the public discourse. Visualisations are now a relatively common element of participatory environmental planning and management processes (Reed et al 2013), especially in relation to my own area of work - sustainable land use. Their use introduces questions around how the images that are generated and used embody, reflect and/or influence the environmental values of both respondents and researchers. In this case the research process, including the visualisation, does appear to have increased participants knowledge of local impacts, risks and costs - with an attendant impact, albeit small, on their preferences for funding options.

Adrian Brügger and Nicholas Pidgeon shift our attention to the ways in which our existing beliefs about and framings of climate change interact with the information from public agencies and others seeking to affect our behaviour. They critically reflect on the assertion that spatially-proximal representations of climate change impacts (considered particularly useful for facilitating visualisation techniques, such as used by Merrill et al above) are likely to affect our motivations more than spatially-distant representations. Framings of climate change have previously drawn criticism within the pages of Environmental Values on account of the problematic representation of impacts temporally. Davies et al. (2017) highlighted the tendency (particularly amongst media actors) towards the description of future impacts and resultant overstatement of contemporary environmental degradation. Through interview research in 


\section{EDITORIAL}

Switzerland, Brügger and Pidgeon problematise established framings further by demonstrating that individuals make frequent reference to both proximal and distant impacts of climate change regardless of the spatial focus of information provided. They make clear that the media, experiences of others within their social network, and personal experiences are all sources of information drawn on by individuals to frame climate change and its impacts.

The process of switching between spatial frames is achieved in a number of ways. Brügger and Pidgeon identify that respondents tend to collapse the distinctions between scales, making distant impacts locally relevant (e.g. by reconciling distant sea-level change with proximal glacial melt). Respondents were also inclined to reveal the personal implications of climate change impacts (e.g. the impact of predicted heatwaves on health) and to construct relationships of resilience and vulnerability. This latter dimension revolved particularly around the economic and environmental resilience of countries such as Switzerland, and vice versa, the vulnerability of already economically and environmentally marginal distant places.

These contributions remind us that environmental policy and management processes are many-headed beasts that can be engaged with, steered and influenced at many stages and in many ways. This is something that perhaps feels less obvious in the aftermath of a high-profile, singular decision-making event such as a referendum. A theme that permeates the papers in this issue, and many previous contributions to Environmental Values, is the strength and relative inertia of existing ways of knowing within policy and management processes - established 'knowledge' that is often resident within and attuned to powerful actors. It is apparent in the NOAA's BiOps that facilitate continued dam operation at the very likely expense of salmon species, and in the discourse that surrounds continued steel production in southern Italy. It is perpetuated by established political processes such as the TRC model described by Esme Murdock and within our own cognitive processes for assimilating information about climate change. That established ways of knowing can set the agenda of environmental management is a phenomenon that has been apparent in my own work (e.g. Dandy et al, 2014) and it has often been the role of contributors to Environmental Values to 'highlight the ways in which existing epistemic frameworks lead to self-fulfilling prophecies that require overturning' (Barr, 2017: 126).

NORMAN DANDY

Bangor University 


\section{EDITORIAL}

\section{REFERENCES}

Bach, T.M. and B.M.H. Larson. 2017. 'Speaking about weeds: Indigenous elders' metaphors for invasive species and their management' Environmental Values 26(5): 561-581. Crossref

Barr, B. 2017. 'Knowledge, expertise and engagement'. Environmental Values 26(2): 125-130. Crossref

Bergsma, E. 2016. 'Geographers versus managers: Expert influence on the construction of values underlying flood insurance in the United States'. Environmental Values 25(6): 687-705. Crossref

Bhattacharyya, J. and B.M.H. Larson. 2014. 'The need for indigenous voices in discourse about introduced species: Insights from a controversy over wild horses', Environmental Values 23(6), 663-684. Crossref

Brügger, A. and N. Pidgeon. 2018. ' Spatial framing, existing associations and climate change beliefs'. Environmental Values 27(5): 559-584.

Dandy, N., S. Fiorini and A.L. Davies. 2014. 'Agenda-setting and power in collaborative natural resource management'. Environmental Conservation 41(4): 311-320. Crossref

Davies, W., S. Wright and J. van Alstine. 2017. 'Framing a "Climate Change Frontier": International news media coverage surrounding natural resource development in Greenland'. Environmental Values 26(4): 481-502. Crossref

Greco, L. and F. Bagnardi. 2018. 'In the name of science and technology: The postpolitical environmental debate and the Taranto steel plant (Italy)'. Environmental Values 27(5): 489-512.

Hirsh, S. and J. Long. 2018. 'Non-epistemic values in adaptive management: Framing possibilities in the legal context of endangered Columbia River salmon'. Environmental Values 27(5): 467-488.

Murdock, E. 2018. 'Unsettling reconciliation: Decolonial methods for transforming social-ecological systems'. Environmental Values 27(5): 513-533.

Merrill, S., J. Kartez, K. Langbehn, F. Muller-Karger and C.J. Reynolds. 2018. 'Who should pay for climate adaptation? Public attitudes and the financing of flood protection in Florida'. Environmental Values 27(5): 535-557.

Reed, M.S., J. Kenter, A. Bonn, K. Broad, T.P. Burt, I.R. Fazey, E.D.G. Fraser, K. Hubacek, D. Nainggolan, C.H. Quinn, L.C. Stringer and F. Ravera. 2013. 'Participatory scenario development for environmental management: A methodological framework illustrated with experience from the UK uplands'. Journal of Environmental Management 128: 345-362. Crossref 


$$
\begin{aligned}
& ?=\text { username } \\
& \text { SREMOTE ASSR = IP address }
\end{aligned}
$$

